\title{
ANALISIS FAKTOR-FAKTOR YANG MEMPENGARUHI PRODUKSI USAHATANI SAYUR-SAYURAN DI KELURAHAN MAHARATU KECAMATAN MARPOYAN DAMAI KOTA PEKANBARU
}

\author{
Jamalludin \\ Dosen Fakultas Pertanian Universitas Islam Kuantan Singingi \\ Email : fit_jamal@yahoo.com
}

\begin{abstract}
ABSTRAK
Tujuan dari penelitian ini adalah untuk mengetahui faktor-faktor produksi yang mempengaruhi produksi usahatani sayur-sayuran di Kelurahan Maharatu Kecamatan Marpoyan Damai Kota Pekanbaru. Metode yang digunakan dalam penelitian ini adalah survey. Penelitian ini dilakukan di Kelurahan Maharatu. Penetapan daerah penelitian ini dilakukan secara sengaja dengan pertimbangan bahwa di daerah tersebut adalah daerah binaan Dinas Pertanian Kota Pekanbaru yang termasuk wilayah program pegembangan hortikultura. Populasi dalam penelitian ini adalah seluruh petani yang mengusahakan komoditisayur-sayuran bayam dan kangkung. Berdasarkan hasil survey pendahuluan diketahui petani yang mengusahakan tanaman sayuran bayam dan kangkung adalah sebanyak 56 orang. Selanjutnya diambil sampel secara sengaja (Purposive Sampling) sebanyak 30 orang petani, dimana sampel tersebut membudidayakan tanaman sayuran bayam, kangkung yang di tanam secara bersamaan.Secara simultan penggunaan faktor produksi luas lahan, benih, pupuk urea, pupuk NPK, pupuk kandang, pestisida dan tenaga kerja dari sayur kangkung dan bayam memberikan pengaruh yang sangat nyata. Berdasarkan nilai koefisien determinan untuk kedua sayuran diketahui bahwa variabel tersebut mampu mempengaruhi produksi kangkung sebesar 93,2\% dan bayam sebesar 73,7\%.Pada sayur kangkung variabel bebas berpengaruh sangat nyata adalah Luas lahan (X1), Benih (X2) dan Pupuk Kandang $\left(\mathrm{X}_{3}\right)$, Tenaga kerja (X5) dan sayur bayam hanya benih (X2) variable bebas berpengaruh sangat nyata. Dapat diketahui bahwa usahatani sayur-sayuran yang dijalankan petani berada di daerah II pada kurva produksi (decreasing rate) karena nilainya lebih besar dari nol dan lebih kecil dari 1. secara matematis dan artinya adalah proporsi penambahan faktor produksi (Luas Lahan, Benih, pupuk, pestisida dan tenaga kerja) secara bersama-sama akan menghasilkan produk marjinal yang lebih kecil dibandingkan penambahan faktor produksi $(\Delta \mathrm{X})$, namun masih bernilai positif.
\end{abstract}

Kata Kunci:Kangkung, Bayam, Analisis Produksi.

PENDAHULUAN

Sektor pertanian Indonesia terdiri dari tiga subsektor yaitu subsektor tanaman perkebunan, tanaman pangan dan hortikultura. Hortikultura sebagai salah satu subsektor pertanian terdiri dari berbagai jenis tanaman hias, sayuran, buah-buahan dan tanaman obatobatan.produk hortikultura khususnya sayuran dan buah-buahan berperan dalam memenuhi gizi masyarakat terutama vitamin dan mineral yang terkandung di dalamnya. Hal ini juga 
penting dalam peningkatan kualitas sumberdaya manusia sebagai pelaku pembangunan ekonomi.

Dalam struktur pembentukan PDB sektor pertanian, sub sektor hortikultura menyumbang sebesar 23 persen dan menempati posisi kedua terbesar setelah tanaman pangan. Sementara itu dalam PDB subsektor hortikultura meliputi urutan kedua setelah tanaman buah dan PDB sayuran juga meningkat dengan laju rata-rata 8 persen pertahun dari 2002-2005 (Deptan, 2006).

Dalam rangka memenuhi kebutuhan pangan masyarakat Indonesia, pemerintah menempuh beberapa upaya diantaranya adalah mengembangkan tanaman hortikultura. Komoditas hortikultura harus ditumbuh kembangkan dalam rangka pemanfaatan peluang dan keunggulan kompetitif berupa iklim yang bervariasi, tanah yang subur, tenaga kerja yang murah dan banyaknya lahan yang tersedia.

Oleh karena itu, pemerintah berusaha untuk lebih memperhatikan sektor pertanian.Hal ini terlihat dengan berbagai program yang ditujukan untuk memacu sektor pertanian seperti keridit usahatani dan pemberdayaan masyarakat pedesaan.

Dengan adanya pembangunan di subsektor tanaman pangan dan hortikultura maka diharapkan mampu untuk meningkatkan produksi dan kesejahteraan petani yang dicapai melalui upaya peningkatan pendapatan, produksi, dan produktivitas usahatani.Namun salah satu kelemahan dalam sistem usahatani adalah aspek pengelolaan/manajemen. Di Indonesia, kelemahan pengelolaan sering dijumpai karena sistem usahatani masih bersifat kekeluargaan.

Berdasarkan agrosistem wilayah, Provinsi Riau sangat sesuai untuk budidaya sayuran dataran rendah karena memiliki iklim dan suhu udara $23,4-33,4^{\circ} \mathrm{C}$, dan curah hujan 2000 $3000 \mathrm{~mm} /$ tahun. Disisi lain kebutuhan akan sayuran dari tahun ketahun cenderung meningkat seiring dengan bertambahnya jumlah penduduk. Kebutuhan sayuran bagi masyarakat Provinsi Riau diperkirakan sekitar 100gr/kapita/hari yang cenderung akan mengalami peningkatan seiring dengan pertambahan jumlah penduduk dan pengetahuan masyarakat akan kesehatan.(Dinas Tanaman Pangan dan Holtikultura Provinsi Riau, 2011).

Produksi tanaman sayur-sayuran di Provinsi Riau pada tahun 2011 sebanyak $16.301,74$ ton,mengalami peningkatan sebesar $11,7 \%$ dari tahun sebelumnya yaitu pada tahun 2010sebanyak 16.111,01 ton.(Kanwil Departemen Pertanian Provinsi Riau, 2012).

Kota Pekanbaru merupakan salah satu daerah yang ada di Provinsi Riau yang ikut mengalami pertumbuhan dan perkembangan pada subsektor bahan tanaman pangan 
khususnya sayur-sayuran. Pada tahun 2013 produksi sayur-sayuran di Kota Pekanbaru mencapai 21.471 ton/tahunnya yang tersebar diseluruh kecamatan yang ada di Kota Pekanbaru. Untuk lebih jelasnya produksi sayur-sayuran di Kota Pekanbaru dapat dilihat pada Tabel 1.

Tabel 1. Produksi Sayur-Sayuran Kota Pekanbaru Berdasarkan Jenis Sayur-sayuran dan Kecamatan Tahun 2013.

\begin{tabular}{|c|c|c|c|c|c|c|c|c|c|c|}
\hline \multirow{2}{*}{ No. } & \multirow{2}{*}{ Kecamatan } & \multicolumn{8}{|c|}{ Jenis Sayur-sayuran (Ton) } & \multirow{2}{*}{ Total Produksi (ton) } \\
\hline & & Timun & Terong & K.Panjang & Bayam & Kangkung & Cabe & Selada & Petai & \\
\hline 1. & Tampan & 372 & 420 & 969 & 1.120 & 1.120 & 295 & 17 & 690 & 5.003 \\
\hline 2. & Payung Sekaki & 36 & 60 & 119 & - & 40 & 45 & - & - & 300 \\
\hline 3. & Bukit Raya & - & - & 17 & 150 & 130 & 10 & - & 330 & 637 \\
\hline 4. & Marpoyan Damai & 36 & - & 119 & 3.240 & 2.040 & 50 & 27 & 2.160 & 7.672 \\
\hline 5. & Tenayan Raya & 312 & 180 & 901 & 240 & 370 & 45 & 22 & - & 2.070 \\
\hline 6. & Lima Puluh & - & - & - & - & - & - & - & - & 0 \\
\hline 7. & Sail & - & - & - & - & 80 & - & - & - & 80 \\
\hline 8. & Pekanbaru Kota & - & - & - & - & - & - & - & - & 0 \\
\hline 9. & Sukajadi & - & - & - & - & - & - & - & - & 0 \\
\hline 10. & Senapelan & - & - & - & - & - & - & - & - & 0 \\
\hline 11. & Rumbai & 852 & 1.080 & 1.632 & 240 & 240 & 605 & - & - & 4.649 \\
\hline 12. & Rumbai Pesisir & 120 & 105 & 255 & 260 & 270 & 50 & - & - & 1.060 \\
\hline & Jumlah & 1.728 & 1.845 & 4.012 & 5.250 & 4.290 & 1.100 & 66 & 3.180 & 21.471 \\
\hline
\end{tabular}

Sumber : BPS Provinsi Riau(2013)

Dilihat dari Tabel 1, produksi sayur-sayuran di Kota Pekanbaru tertinggi yaitu pada jenis sayuran bayam dan kangkung yaitu sebanyak 5.250 ton dan 4.290 ton per tahunnya. Sedangkan jika dilihat menurut Kecamatan yang ada di Kota Pekanbaru, maka dapat dilihat bahwa Kecamatan Marpoyan Damai merupakan kecamatan yang memiliki produksi tertinggi yaitu sebanyak 7.672 ton/tahun.

Usahatani sayuran di Kelurahan Maharatu menggunakan pola diversifikasi dengan menanam lebih dari satu jenis tanaman.Dalam satu lahan petani biasa menanam dua jenis sayuran sekaligus dengan waktu yang bersamaan.Misalnya petani menanam kangkung dan bayam secara bersama.Karena waktu panen kedua sayuran tersebut bersamaan, maka petani tidak mengalami masalah jika menanam kedua jenis sayuran tersebut secara bersamaan pada satu tempat. Dengan pola tanam yang berbeda maka kemungkinan akan terdapat pula 
perbedaan pengunaan input, biaya produksi, dan produksi yang dihasilkan, dimana pada akhirnya akan dapat pula berpengaruh terhadap pendapatan petani. Namun sejauh ini peningkatan produksi sayur-sayuran dari masing-masing sayuran tersebut belum diketahui, begitu pula pendapatan yang diperoleh oleh petani. Masih kurangnya pengetahuan petani tentang efisiensi penggunaan faktor produksi seperti pengolahan lahan, pengunaan benih, pemupukan, pengunaan pestisida dan tenaga kerja sehinga upaya peningkatan produksi dan pendapatan usahatani sayuran dapat menjadi terhambat. Berkaitan dengan itulah saya tertarik ingin melakukan penelitian ini.

\section{METODE PENELITIAN}

Metode yang digunakan dalam penelitian ini adalah survey. Penelitian ini dilakukan di Kelurahan Maharatu. Penetapan daerah penelitian ini dilakukan secara sengaja dengan pertimbangan bahwa di daerah tersebut adalah daerah binaan Dinas Pertanian Kota Pekanbaru yang termasuk wilayah program pegembangan hortikultura.

Populasi dalam penelitian ini adalah seluruh petani yang mengusahakan komoditisayur-sayuran bayam dan kangkung. Berdasarkan hasil survey pendahuluan diketahui petani yang mengusahakan tanaman sayuran bayam dan kangkung adalah sebanyak 56 orang. Selanjutnya diambil sampel secara sengaja (Purposive Sampling) sebanyak 30 orang petani, dimana sampel tersebut membudidayakan tanaman sayuran bayam, kangkung yang di tanam secara bersamaan.

\section{Analisis Fungsi Produksi}

Pengaruh faktor-faktor produksi terhadap produksi dan pendapatan pada petani di gunakan Metode analisis Regesi dengan fungsi produksi Cobb-Douglas. Data yang terkumpul di lakukan analisis. Model statistik yang digunakan adalah dengan fungsi produksi Cobb-Douglas.

Menurut Soekartawi (1986), fungsi produksi Cobb-Douglas dapat dilihat dengan ekonometrik ditulis sebagai berikut:

$$
\begin{array}{ll}
\text { Populasi: } & \mathrm{Y}=\mathrm{A} \mathrm{X}{ }_{1}^{\mathrm{B} 1} \mathrm{X}_{2}^{\mathrm{B} 2} \mathrm{X}_{3}^{\mathrm{B} 3} \mathrm{X}_{4}^{\mathrm{B} 4} \mathrm{X}_{5}^{\mathrm{B} 5}+\mathrm{e}_{\mathrm{i}} \\
\text { Sampel: } & \mathrm{Y}=\mathrm{a}_{\mathrm{o}} \mathrm{X}^{\mathrm{b} 1} \mathrm{X}_{2}^{\mathrm{b} 2} \mathrm{X}_{3}^{\mathrm{b} 3} \mathrm{X}_{4}^{\mathrm{b} 4} \mathrm{X}_{5}^{\mathrm{b} 5}+\mathrm{e}_{\mathrm{i}}
\end{array}
$$

Untuk mempermudah pendugaan terhadap persamaan tersebut maka diubah menjadi bentuk log linear berganda dengan cara mentransformasikan ke dalam persamaan logaritma natural (Ln), sehinga menjadi:

$\operatorname{Ln} \mathrm{Y}=1 \mathrm{n} \mathrm{a}+\mathrm{b} 11 \mathrm{n} \mathrm{X} 1+\mathrm{b} 2 \ln \mathrm{X} 2+\mathrm{b} 3 \ln \mathrm{X} 3+\mathrm{b} 4 \ln \mathrm{X} 4+\mathrm{b} 5 \ln \mathrm{X} 5+\mathrm{e}_{\mathrm{i}} \ldots$ 
Yang telah dimasukkan dalam analisis sebagai berikut:

Dimana:

$$
\begin{array}{ll}
\mathrm{Y} & =\text { Produksi (Kg/Musim Tanam) } \\
\mathrm{X} 1 & =\text { Luas Lahan (Ha/Musim Tanam) } \\
\mathrm{X} 2 & =\text { Benih }(\mathrm{Kg} / \text { Musim Tanam }) \\
\mathrm{X} 3 & =\text { Pupuk (Kg/Musim Tanam) } \\
\mathrm{X} 4 \quad=\text { Pestisida (Liter/Musim Tanam) } \\
\mathrm{X} 5 \quad=\text { Tenaga Kerja (HKP/Ha/Musim Tanam) } \\
\mathrm{a} \quad=\text { Intercept } \\
\mathrm{e}_{\mathrm{i}} \quad=\text { Komponen Pengganggu } \\
\mathrm{b} 1, \mathrm{~b} 2, \mathrm{~b} 3, \mathrm{~b} 4, \text { b5 = Parameter Peduga }
\end{array}
$$

\section{HASIL DAN PEMBAHASAN}

Analisis fungsi produksi merupakan lanjutan dari aplikasi analisis regresi, yaitu analisis yang menjelaskan hubungan sebab akibat. Jadi bilaY (Produksi) dipenggaruhi oleh pupuk (X), maka pupuk akan selalu mempenggaruhi produksi dan tidak akan jadi sebaliknya (produksi mempenggaruhi jumlah pupuk yang dipakai). Secara singkat, fungsi produksi diartikan sebagai suatu model yang menyatakan hubungan X dan Y (Soekartawi, 1995).

\section{Pembentukan Fungsi Produksi}

Untuk mengetahui berbagai variabel bebas (independen variabel) terhadap variabel terikat (dependen variabel) dianalisis dengan menggunakan persamaan regresiberganda dengan bantuanSPSS. Berdasarkan output dari progam tersebut, kemudian dibentuk fungsi produksi.

Menurut Soekartawi (2003), untuk mendapatkan garis regesi yang baik (goodness of fit),ada beberapa cara yang dapat dilakukan yaitu: 1). Menentukan satuan yang tepat dalam mengukur variabel, misalkan untuk mengetahui pengaruh luas lahan terhadap produksi digunakan satuan luas (hekter) sedangkan untuk mengetahui pengaruhnya terhadap pendapatan biasanya digunakan biaya atas kepemilikan lahan tersebut (Rp). 2). Menambah atau mengurangi variabel yang dipakai dalam analisis. 3). Membuat percobaan denganmenggunakan beragam cara, minsalnya mengunakan garis linier atau non-linear dan 4). Membuat analisis bertahap (stepwise analysis).

Analisis pengaruh faktor-faktor produksi terhadap produksi sayur-sayuran, analisis ini dilakukan dengan program SPSS berdasarkan data penggunaan faktor-faktor produksi dan jumlah produksi sayur-sayuran. 
Dari hasil analisis tranformasi logaritma natural data faktor-faktor produksi dan jumlah produksi dari dua sayuran, terdapat data pada Tabel2:

Tabel 2. Koefisien Regresi Faktor-faktor Yang BerpengaruhTerhadap Produksi Sayursayuran Di Kelurahan Maharatu Kecamatan Marpoyan Damai

\begin{tabular}{|c|c|c|c|c|}
\hline \multirow{3}{*}{$\begin{array}{l}\text { Indevendent Variabel } \\
\qquad(\mathrm{Xi})\end{array}$} & \multicolumn{4}{|c|}{ Varietas } \\
\hline & \multicolumn{2}{|c|}{ Kangkung } & \multicolumn{2}{|c|}{ Bayam } \\
\hline & $\begin{array}{l}\text { Koefisien } \\
\text { Regresi (b) }\end{array}$ & Sig & $\begin{array}{l}\text { Koefisien } \\
\text { Regresi (b) }\end{array}$ & Sig \\
\hline Constan/intercept & $-458,286$ & 0,012 & $-162,050$ & 0,513 \\
\hline Luas Lahan (X1) & 0,940 & $0,004^{\text {**** }}$ & 0,226 & 0,381 \\
\hline Benih (X2) & $-0,997$ & $0,003^{\text {***** }}$ & $-0,455$ & $0,020^{* * *}$ \\
\hline P. Urea $\left(X 3_{1}\right)$ & $-0,063$ & 0,633 & 0,417 & 0,238 \\
\hline P. NPK $\left(X 3_{2}\right)$ & $-0,351$ & $0,022^{* *}$ & $-0,836$ & 0,119 \\
\hline P.Kandang $\left(\mathrm{X} 3_{3}\right)$ & 1,094 & $0,000^{* * * *}$ & 1,016 & 0,121 \\
\hline Pestisida (X4) & 0,029 & 0,152 & 0,038 & 0,490 \\
\hline T.Kerja (X5) & 0,437 & $0,012^{* *}$ & 0,426 & 0,106 \\
\hline $\mathrm{R}^{2}$ & 0,932 & - & 0,737 & - \\
\hline Adj. $R^{2}$ & 0,910 & - & 0,653 & - \\
\hline F Sig & 0,000 & - & 0,000 & - \\
\hline
\end{tabular}

Ket $:^{* * *}=$ sangat nyata pada $\alpha 0,01$

** $\quad=$ Nyata pada $\alpha 0,05$

" = Nyata pada $\alpha 0,1$

Pada Tabel 2 diketahui fungsi produksi dalam penggunaan sayuran kangkung dan bayam terbaik adalah pada persamaan sayur kangkung.

Dari ke dua sayuran persamaan yang terbentuk dari analisis regresi linear berganda adalah:

1. Kangkung

$$
\begin{gathered}
Y=-458,286 X_{1}{ }^{0,940} X_{2}{ }^{-0,997} X_{31}{ }^{-0,063} X_{32}{ }^{-0,351} X_{33}{ }^{1,094} X_{4}{ }^{0,029} X_{5}{ }^{0,437} \\
Y=-458,286(1,907)^{0,940}(31)^{-0,997}(13)^{-0,063}(12)^{-0,351} \\
(1452)^{1,094}(0,39)^{0,029}(16,91)^{0,437}
\end{gathered}
$$

Dalam bentuk Logaritma Natural (Ln) persamaan tersebut menjadi:

$$
\begin{aligned}
& \operatorname{Ln} Y=\operatorname{Ln}-458,286+0,940 \operatorname{Ln} X_{1}-0,997 \operatorname{Ln} X_{2}-0,063 \operatorname{Ln} X_{31}-0,351 \operatorname{Ln} X_{32}+ \\
& 1,094 \operatorname{Ln} X_{33}+0,029 \operatorname{Ln} X_{4}+0,437 \operatorname{Ln} X_{5}
\end{aligned}
$$

2. Bayam

$$
\begin{aligned}
& \mathrm{Y}=-162,050 \mathrm{X}_{1}{ }^{0,226} \mathrm{X}_{2}{ }^{-0,455} \mathrm{X}_{31}{ }^{0,417} \mathrm{X}_{32}{ }^{-0,836} \mathrm{X}_{33}{ }^{1,016} \mathrm{X}_{4}{ }^{0,038} \mathrm{X}_{5}{ }^{0,426} \\
& Y=-162,050(1,544)^{0,226}(3,72)^{-0,455}(11)^{0,417}(10)^{-0,836} \\
& (1220)^{1,016}(0,44)^{0,038}(12,29)^{0,426}
\end{aligned}
$$


Dalam bentuk Logaritma Natural (Ln) persamaan tersebut menjadi:

$\operatorname{Ln} Y=\operatorname{Ln}-162,050+0,226 \operatorname{Ln} X_{1}-0,455 \operatorname{Ln} X_{2}+0,417 \operatorname{Ln} X_{31}-0,836 \operatorname{Ln} X_{32}+$ $1,016 \operatorname{Ln} X_{33}+0,038 \operatorname{Ln} X_{4}+0,426 \operatorname{Ln} X_{5}$

Dari persamaan dua sayuran yang diatas sebagai fungsi produksi adalah persamaan yang memiliki garis peduga yang baik. Hal ini akan terpenuhi apabila memenuhi persyaratan sebagai berikut ; a). berdasarkan uji F maka variabel yang dipilih dalam persamaan signifikan pada taraf kepercayaan tertentu; b). besarnya koefisien determinansi atau $R^{2}$; c). uji t terhadap masing-masing koefisien regresi adalah nyata pada tingkat kepercayaan tertentu; d). besaran nilai koefisien regresi adalah sesuai dengan teori dan logika; e). berdasarkan matrik korelasi apakah ada multikolinieritas (Soekartawi 2003).

Dari Tabel 2 diketahui nilai F sig dari kedua sayur kangkung dan bayam adalah, 0,000 ini berarti variabel-variabel bebas yang ada pada kedua sayur tersebut secara bersama-sama memiliki hubungan yang sama eratnya terhadap variabel terikat, hal ini teruji pada tingkat keyakinan $99 \%$.

Pada tahapan berikutnya, untuk kedua sayuran diketahui nilai koefisien determinasinya $\left(\mathrm{R}^{2}\right)$ dan dapat dilihat pada Table 2. Dari kedua bila dilihat dari nilai t Sig kedua sayuran, ternyata persamaan yang memiliki garis peduga yang paling baik, karena terdapat variabel bebas berpengaruh sangat nyata mempunyai pengaruh terhadap variabel terikat, lebih jelasnya dapat dilihat pada sayur kangkung variabel bebas berpengaruh sangat nyata adalah Luas lahan (X1), Benih (X2) dan Pupuk Kandang (X3 3 ), Tenaga kerja (X5) dan sayur bayam hanya benih (X2) variable bebas berpengaruh sangat nyata, lebih jelasnya dapat dilihat pada Tabel 2.

Berdasarkan metrik korelasi dari kedua sayuran multikolineritas pada penguji menunjukan bahwa garis peduga yang cukup baik.Nilai F Sig dari kedua sayuran pengunaan kangkung adalah 0,000 dan sayur bayam adalah 0,000 artinya adalah, variabel bebas Luas Lahan $\left(\operatorname{Ln~} X_{1}\right)$, Benih $\left(\operatorname{Ln~} X_{2}\right)$, Pupuk $\left(\operatorname{Ln~} X_{3}\right)$, Pestisida $\left(\operatorname{Ln~} X_{4}\right)$ dan Tenaga Kerja $\left(\operatorname{Ln} X_{5}\right)$ secara bersama-sama pengaruhnya nyata terhadap produksi. Besarnya pengaruh tersubut ditunjukan oleh koefisien determinasi $\left(\mathrm{R}^{2}\right)$ untuk Kangkung yaitu sebesar 0,932 hal ini memiliki pengertian bahwa, secara simultan variabel-variabel tersebut akan mampu menentukan tinggi rendahnya produksi sebesar 93,2\% dan sisanya sebesar 6,8\% ditentukan oleh variabel lain yang tidak dimasukan dalam pearsamaan. 
Koefisien determinasi $\left(\mathrm{R}^{2}\right)$, untuk sayur Bayam yaitu sebesar 0,737 hal ini memiliki pengertian bahwa, secara simultan variabel-variabel tersebut akan mampu menentukan tinggi rendahnya produksi sebesar $73,7 \%$ dan sisanya sebesar $26,3 \%$ ditentukan oleh variabel lain yang tidak dimasukan dalam pearsamaan.

Dengan demikian maka hipotesis $1 \mathrm{H}_{\mathrm{o}}$ yang meanyatakan bahwa luas lahan, benih, pupuk, pestisida dan tenaga kerja tidak berpengaruh nyata terhadap produksi adalah ditolak dan hipotesis $1 \mathrm{H}_{\mathrm{a}}$ diterima. Dari uji $\mathrm{t}$ kedua sayur dari variabel bebas yang dimasukan dalam uji tersebut ternyata yang memiliki pengaruh sangat nyata terhadap produksi dapat dilihat pada Table 2. Pada Table 2 dapat dilihat bahwa penggunaan sarana produksi dan keberadaanya harus benar-benar diperhatikan oleh petani. Dalam upaya peningkatan produksi, perlu diketahui variabel apa saja yang benar-benar berpeangaruh terhadap produksi, dengan deamikian petani akan lebih mudah untuk menggetahuinya. Sehinga petani bisa produksi yang optimal dan keuntungan yang maksimal dapat dicapai oleh peatani.

\section{Interprestasi Nilai Koefisien Regresi (b) dan Signifikasi t}

\section{Kangkung}

Berdasarkan analisis yang dilakukan dan fungsi produksi yang terbentuk, diketahuai bahwa besaran nilai koefisien regresi untuk Luas lahan adalah 0,940 Benih -0,997, pupuk Urea -0,063, pupuk NPK -0,351, pupuk kandang 1,094, Pestisida 0,029dan Tenaga kerja 0,437. Sedangkan nilai signifikasi t untuk Luas lahan adalah 0,004, Benih 0,003, P.Urea 0,633, P.NPK 0,022, P.kandang 0,000, Pestisida 0,152 dan Tenaga kerja 0,012.

Adapun hasil analisis regresi terhadap variable yang digunakan diduga mempengaruhi tingkat produksi usahatani sayur-sayuran di Kelurahan Maharatu Kecamatan marpoyan Damai, variable berpengaruh secara signifikan adalah :

a. Luas Lahan (X1)

Nilai koefisien regresi untuk luas lahan adalah sebesar 0,940 artinya adalah setiap peningkatan satu persen luas lahan yang digunakan untuk berusahatani sayur kangkung, ternyata mampu meningkatkan produksi sebesar 0,940 persen, adapun nilai signifikansi t untuk variabel ini adalah sebesar 0,004ini artinya pada tingkat kepercayaan 99\% terbukti bahwa luas lahan sanggat berpengaruh nyata terhadap jumlah produksi. Terlihat bahwa kontribusi luas lahan relatif besar dan berhubungan secara positif terhadap tingkat produksi. Koefisien regresi yang bertanda positif menunjukan semangkin tinggi luas lahan maka semakin tinggi tingkat produksi hal ini disebabkan lahan yang subur, akan mencukupi 
kebutuhan tanaman terhadap unsur hara dan berprodusi tinggi. Sehingga setiap meningkatan luas lahan akan diikuti oleh peningkatan produksi tanaman kangkung. Terlihat bahwa terjadi peningkatan produksi yang sangat tinggi dengan adanya perluas lahan, namun untuk pengembangan lahan usahatani sayur kangkung sekarang sudah mengalami penyempitan karena banyak lahan pertanian beralih pungsi sebagai perumahan atau pemukiman masyarakat.

b. Benih (X2)

Jumlah penggunaan benih oleh petani sampel memiliki nilai koefisien regresi sebesar -0,997, ini berartibahwa penggunaan benih berhubungan negative terhadap produksi, dimana setiap peningkatan jumlah penggunaan benih 1 persen, akan berdampak pada menurunnya jumlah produksi sebesar 0,997 persen, sedangkan nilai signifikansi t pada variabel ini adalah 0,003 artinya, pada tingkat kepercayaan $95 \%$ terbukti bahwa penggunaan benih berpengaruh nyata terhadap jumlah produksi. Hal ini disebabkan penggunaan benih oleh petani sudah berlebih, maka penggunaan benih harus dikurangi.

c. Pupuk NPK

Jumlah penggunaan pupuk NPK oleh petani sampel memiliki nilai koefisien regresi sebesar -0,351, ini berartibahwa penggunaan pupuk NPK berhubungan negative terhadap produksi, dimana setiap peningkatan jumlah penggunaan pupuk NPK 1 persen, akan berdampak pada menurunnya jumlah produksi sebesar 0,351persen, sedangkan nilai signifikansi t pada variabel ini adalah 0,022 artinya, pada tingkat kepercayaan 95\% terbukti bahwa penggunaan pupuk NPK berpengaruh nyata terhadap jumlah produksi. Hal ini disebabkan penggunaan pupuk NPK oleh petani sudah berlebih, maka penggunaan pupuk NPK harus dikurangi.

d. Pupuk Kandang $\left(\mathrm{X}_{3}\right)$

Jumlah penggunaan pupuk kandang oleh petani sampel memiliki nilai koefisien regresi sebesar 1,094, ini betrartibahwa setiap peningkatan penggunaan pupuk kandang 1 persen, akan diikuti oleh peningkatan produksi sebesar 1,094 persen, sedangkan nilai signifikansi t pada variabel ini adalah 0,000 artinya, penggunaan pupuk kandang sangat berpengaruh nyata terhadap jumlah produksi. Terlihat bahwa kontribusi penggunaan pupuk kandang relatif besar dan berhubungan secara positif terhadap tingkat produksi. Pupuk kandang merupakan faktor penting dan perlu diperhitungkan dalam proses produksi 
komunitas usahatani sayuran kangkung. Penggunaan pupuk kandang dapat dinyatakan sebagai curahan pupuk kandang atau besaranyapupuk kandang efektif yang dipakai.

e. Tenaga kerja (X5)

Jumlah penggunaan tenaga kerja oleh petani memiliki nilai koefisien regresi sebesar 0,437 ini betrartibahwa setiap peningkatan penggunaan tenaga kerja 1 persen, tenaga kerja yang digunakan untuk berusahatani sayur kangkung, ternyata mampu meningkatkan produksi sebesar 0,437 persen, adapun nilai signifikansi $t$ untuk variabel ini adalah sebesar 0,012ini artinya pada tingkat kepercayaan $99 \%$ terbukti bahwa penggunaan tenaga kerja sanggat berpengaruh nyata terhadap jumlah produksi. Terlihat bahwa kontribusi penggunaan tenaga kerja relatif berperan dan berhubungan secara positif terhadap tingkat produksi. Koefisien regresi yang bertanda positif menunjukan semangkin tinggi penggunaan tenaga kerja maka semakin tinggi tingkat produksi hal ini disebabkan produktifitas tenaga kerja dan jumlah orang dalam berkerja. Sehingga setiap peningkatan tenaga kerja akan diikuti oleh peningkatan produksi tanaman sayur kangkung. Terlihat bahwa terjadi peningkatan produksi yang sangat tinggi dengan adanya peningkatan tenaga kerja.

Sedangkan variable yang tidak berpengaruh secara signifikan adalah : Pupuk UREA (X31), Pestisida (X4).

a. Pupuk UREA $\left(\mathrm{X} 3_{1}\right)$

Pupuk UREA memiliki koefisien regresi sebesar -0,063 ini betrartibahwa penggunaan pupuk UREA berhubungan negatif terhadap produksi, dimana setiap peningkatan jumlah penggunaan pupuk UREA sebesar 1 persen, akan berdampak pada menurunya jumlah produksi sebesar 0,063 persen, adapunniilai signifikansi $t$ untuk penggunaan pupuk UREA oleh petani adalah 0,633 berarti penggunaan pupuk UREA tidak berpengaruh nyata terhadap jumlah produksi.Karena penggunaan pupuk UREA oleh petani sudah berlebihan maka akan menyebabkan produksi yang rendah.

b. Pestisida (X4)

Penggunaan pestisida memiliki nilai koefisien regresi sebesar 0,029, ini betrartibahwa setiap peningkatan penggunaan pestisida 1 persen, akan diikuti oleh peningkatan produksi sebesar 0,029 persen.Sedangkan nilai signifikansi t pada variabel ini adalah 0,152 artinya, penggunaan pestisida berpenggaruh nyata terhadap jumlah produksi. Terlihat bahwa penggunaan pestisida berhubungan positif dengan peningkatan produksi 
usahatani sayur kangkung karena, penggunaan pestisida akan memenuhi kebutuhan tanaman kangkung terhidar dari hama dan penyakit.

\section{Bayam}

Berdasarkan analisis yang dilakukan dan fungsi produksi yang terbentuk, diketahui bahwa besaran nilai koefisien regresi untuk luas lahan adalah 0,226 benih - 0,455 , pupuk Urea 0,417, pupuk NPK -0,836, pupuk kandang 1,016, Pestisida 0,038dan Tenaga kerja 0,426. Sedangkan nilai signifikasi t untuk luas lahan adalah 0,381, Benih 0,020, P.Urea 0,238, P.NPK 0,119, P. kandang 0,121, Pestisida 0,490 dan Tenaga kerja 0,106. Dengan demikian dapat diartikan sebagai berikut:

Adapun hasil analisis regresi terhadap variable yang digunakan diduga mempengaruhi tingkat produksi usahatani sayur bayam di Kelurahan Maharatu Kecamatan Marpoyan Damai, variable berpengaruh secara signifikan adalah :

a. Benih (X2)

Nilai koefisien regresi untuk penggunaan benih adalah sebesar $-0,455$, artinya adalah bahwa penggunaan benih berhubungan negatif terhadap produksi, dimana setiap peningkatan jumlah penggunaan benih sebesar 1 persen, akan berdampak pada menurunnya jumlah produksi sebesar 0,455 persen. Nilai signifikansi t untuk variabel ini adalah sebesar 0,020,ini artinya pada tingkat kepercayaan 95\% terbukti bahwa penggunaan benih berpengaruh nyata terhadap jumlah produksi. Hal ini disebabkan penggunaan benih oleh petani sudah berlebih, maka penggunaan benih harus dikurangi.

Sedangkan variable yang tidak berpengaruh secara signifikan adalah : Luas lahan (X1), Pupuk UREA (X3 $\left.3_{1}\right)$, Pupuk NPK $\left(\mathrm{X} 3_{2}\right)$, Pupuk Kandang $\left(\mathrm{X} 3_{3}\right)$, Pestisida (X4) dan Tenaga kerja (X5).

a. Luas Lahan (X1)

Nilai koefisien regresi untuk luas lahan adalah sebesar 0,226artinya setiap peningkatan 1 persen luas lahan yang digunakan untuk berusahatani sayur bayam, ternyata mampu meningkatkan produksi sebesar 0,226 persen, adapun nilai signifikan $t$ untuk variabel ini adalah sebesar 0,381, ini artinya bahwa luas lahan berpengaruh nyata terhadap jumlah produksi. Terlihat bahwa kontribusi luas lahan relatif besar dan berhubungan secara positif terhadap tingkat produksi. Koefisien regresi yang bertanda positif menunjukan semakin tinggi luas lahan maka semakin tinggi tingkat produksi, hal ini disebabkan lahan yang subur, akan mencukupi kebutuhan tanaman terhadap unsur hara dan berproduksi tinggi. 
Sehingga setiap meningkatan luas lahan akan diikuti oleh peningkatan produksi tanaman sayur bayam. Terlihat bahwa terjadi peningkatan produksi yang sangat tinggi dengan adanya perluas lahan, namun untuk pengembangan lahan usahatani sayur bayamn sekarang sudah mengalami penyempitan karena banyak lahan pertanian beralih pungsi sebagai pemukiman masyarakat.

b. Pupuk UREA $\left(\mathrm{X}_{1}\right)$

Nilai koefisien regresi untuk penggunaan pupuk UREA adalah sebesar 0,417,artinya setiap peningkatan satu persen pengunaan pupuk UREA pada usahatani sayur bayam, akan mampu meningkatkan produksi sebesar 0,417 persen. Nilai signifikansi t untuk variabel ini adalah sebesar 0,238,artinya pupuk UREA berpengaruh terhadap jumlah produksi. Koefisien jumlah pupuk UREA rendah menunjukan pengaruh jumlah pupuk UREA relatif kecil terhadap peningkatan produksi, disebabkan kurangnya pemberian pupuk UREA.

c. Pupuk NPK (X32)

Penggunaan pupuk NPK memiliki koefisien regresi sebesar -0,836, ini betrartibahwa penggunaanpupuk NPK berhubungan negatif terhadap produksi, dimana setiap peningkatan jumlah penggunaan pupuk NPK sebesar 1 persen, akan berdampak pada menurunnya jumlah produksi sebesar 0,836 persen. Nilai signifikansi $t$ untuk penggunaan pupuk NPK oleh petani adalah 0,119, berarti penggunaan pupuk NPK tidak berpengaruh terhadap jumlah produksi.Hal ini disebabkan penggunaan pupuk NPK oleh petani sudah berlebih maka penggunaan pupuk NPK harus dikurangi hal ini disebabkan penggunaannya sudah berlebihan.

d. Pupuk Kandang (X33)

Jumlah penggunaan pupuk Kandang oleh petani sampel memiliki nilai koefisien regresi sebesar 1,016, ini betrartibahwa setiap peningkatan penggunaan pupuk Organik 1 persen akan diikuti oleh peningkatan produksi sebesar 1,016 persen, sedangkan nilai signifikansi $\mathrm{t}$ pada variabel ini adalah 0,121 , artinya penggunaan pupuk Kandang berpengaruh terhadap jumlah produksi.Terlihat bahwa penggunaan pupuk Kandang berhubungan positif dengan peningkatan produksi sayur bayam dan memiliki kontribusi yang besar terhadap produksi. Hal ini disebabkan penggunaan pupuk Kandang akan memperbaiki tekstur tanah menjadi lebih subur. 
e. Pestisida (X4)

Jumlah penggunaan pestisida oleh petani sampel memiliki nilai koefisien regresi sebesar 0,038 ini berartibahwa setiap peningkatan penggunaan pestisida 1 persen, akan diikuti oleh peningkatan produksi sebesar 0,038 persen,sedangkan nilai signifikansi t pada variabel ini adalah 0,490 artinya, penggunaan pestisida berpenggaruh nyata terhadap jumlah produksi. Terlihat bahwa kontribusi penggunaan pestisida relatif besar dan berhubungan secara positif terhadap tingkat produksi, maka dengan pengunaan pestisida ini dapat melindungi tanaman dari gulma dan serangan hama dan penyakit. Pengunaan pestisida baru dilakukan apabila tingkat serangan hama dan penyakit sudah tinggi.

\section{f. Tenaga Kerja (X5)}

Jumlah penggunaan tenaga kerja oleh petani memiliki nilai koefisien regresi sebesar 0,426, ini betrartibahwa setiap peningkatan penggunaan tenaga kerja 1 persen, akan diikuti oleh peningkatan produksi sebesar 0,426 persen, sedangkan nilai signifikansi t pada variabel ini adalah 0,106, artinya penggunaan tenaga kerja berpengaruh terhadap jumlah produksi. Terlihat bahwa kontribusi penggunaan tenaga kerja relatif besar dan berhubungan secara positif terhadap tingkat produksi. Tenaga kerja merupakan faktor penting dan perlu diperhitungkan dalam proses produksi komunitas pertanian. Penggunaan tenaga kerja dapat dinyatakan sebagai curahan tenaga kerja atau besarnya tenaga kerja efektif yang dipakai.

\subsubsection{Return to Scale (RTS)}

Return to scale merupakan satu metode yang digunakan untuk menentukan pada daerah manakah di kurva produksi seseorang petani rasional berproduksi. Metode ini dilakukan dengan cara menjumlahkan seluruh koefisien regresi (parameter elastisitas) dari variabel-variabel independen yang ditetapkan dalam persamaan. Analisis ini juga sering dikaitkan dengan penilaian efisiensi penggunaan faktor produksi secara teknis (Rohim dan Diah, 2000).

Setelah semua koefisien regresi dari variabel bebas Luas Lahan, Benih, Pestisida dijumlahkan, maka Adj. $\mathrm{R}^{2}$ dan Decreasing rate dapat dilihat pada Tabel 3.

Tabel 3. Adj. $\mathrm{R}^{2}$ dan Decreasing rate Pada Sayur Kangkung dan Sayur Bayam.

\begin{tabular}{|c|c|c|}
\hline Sayur & Adj. $\mathrm{R}^{2}$ & Decreasing rate \\
\hline Kangkung & 0,910 & $0>0,910<1$ \\
\hline Bayam & 0,653 & $0>0,653<1$ \\
\hline
\end{tabular}


Dari angka Tabel 3 tersebut dapat diketahui bahwa usahatani yang dijalankan petani berada di daerah II pada kurva produksi (decreasing rate) karena nilainya lebih besar dari nol dan lebih kecil dari 1. secara matematis dan artinya adalah proporsi penambahan faktor produksi (Luas Lahan, Benih, pupuk, pestisida dan tenaga kerja) secara bersama-sama akan menghasilkan produk marjinal yang lebih kecil dibandingkan penambahan faktor produksi $(\Delta \mathrm{X})$, namun masih bernilai positif.

Dari nilai prameter elastisitas, diketahui bahwa petani sampel berproduksi didaerah II, pada daerah ini produksi yang diperoleh belum maksimal padahal total produksi (TP) masih bisa ditingkatkan dengan menambahkan faktor produksi, hinga produksi akan maksimal pada titik B (dapat dilihat kurva produksi pada Gambar 6) akibat penambahan faktor produksi tersebut, produk marjinal (MPP) akan berkurang hingga bernilai negatif, namun penambahan faktor produksi tersebut harus dihentikan pada saat MPP sama dengan nol, saat itulah produksi akan maksimal dan effisiensi teknis dapat dicapai.

Sedangkan elastisitas produksi (Ep) adalah persentase perubahan dari ouput sebagai akibat dari persentase perubahan input, hal ini menunjukan bahwa dalam tahapan usaha terjadi prestiwa pertambahan input yang menyebabkan tambahan output yang semakin menaik (increasing rate) kemudian menurun (descreasing negative) sampai pada produk marginal (PM) yang negatif.

Dalam teori ekonomi asumsi dasar sifat fungsi produksi adalah hukum kenaikan hasil yang semakin berkurang (The law of Diminishing Return). Spesifikasi bentuk fungsi produksi dapat dijabarkan tiga tahap yang secara umum hubungan-hubungan tersebut dapat dijelaskan sebagai berikut:

Tahap I nilai Ep >1 Produk total, produk rata-rata menaik dan produk marginal juga nilainya menaik kemudian menurun sampai nilainya sama dengan produk rata-rata, merupakan daerah irasional karena produsen masih dapat meningkatkan output melalui peningkatan input.

Tahap II nilai Ep adalah $1>\mathrm{EP}>0$, produk total menaik tetapi produk rata-rata menurun dan produk marginal nilainya juga menurun sampai 0 dan merupakan daerah rasional untuk membuat keputusan produksi dan daerah ini terjadi efisien.

Tahap III nilai Ep<0, produk total dan produk rata-rata menurun sedangkan nilai produk marginal negatif, juga merupakan daerah irrasional karena dengan penambahan input akan mengurangi ouput. 


\section{KESIMPULAN}

Secara simultan penggunaan faktor produksi luas lahan, benih, Pupuk Urea, Pupuk NPK, Pupuk kandang, pestisida dan tenaga kerja dari sayur kangkung dan bayam memberikan pengaruh yang sangat nyata. Berdasarkan nilai Koefisien determinan untuk kedua varietas diketahui bahwa variabel tersebut mampu mempengaruhi produksi kangkung sebesar 93,2\% dan bayam sebesar 73,7\%. Pada sayur kangkung variabel bebas berpengaruh sangat nyata adalah Luas lahan (X1), Benih (X2) dan Pupuk Kandang (X3 3 ), Tenaga kerja (X5) dan sayur bayam hanya benih (X2) variable bebas berpengaruh sangat nyata. Dapat diketahui bahwa usahatani sayur-sayuran yang dijalankan petani berada di daerah II pada kurva produksi (decreasing rate) karena nilainya lebih besar dari nol dan lebih kecil dari 1. secara matematis dan artinya adalah proporsi penambahan faktor produksi (Luas Lahan, Benih, pupuk, pestisida dan tenaga kerja) secara bersama-sama akan menghasilkan produk marjinal yang lebih kecil dibandingkan penambahan faktor produksi $(\Delta \mathrm{X})$, namun masih bernilai positif.

\section{Saran}

dapat dilihat bahwa penggunaan sarana produksi dan keberadaanya harus benar-benar diperhatikan oleh petani.Dalam upaya peningkatan produksi, perlu diketahui variabel apa saja yang benar-benar berpeangaruh terhadap produksi, dengan deamikian petani akan lebih mudah untuk menggetahuinya. Sehinga petani bisa produksi yang optimal dan keuntungan yang maksimal dapat dicapai oleh peatani.

\section{DAFTAR PUSTAKA}

Badan Ketahanan Pangan Provinsi Riau. 2005. Analisis Ketersediaan, Distribusi dan Harga Pangan. Pemerintah Daerah Provinsi Riau. Pekanbaru.

Badan Pusat Statistik,2012. Nilai Produk Domestik Bruto Nasional atas Dasar Harga Berlaku Menurut Lapangan Usaha (Milyar Rupiah). Statistik Indonesia.

,2013. Nilai Produk Domestik Regional Bruto Provinsi Riau atas Dasar Harga Berlaku Menurut Lapangan Usaha (Juta Rupiah). Statistik Provinsi Riau. Pekanbaru.

. Produksi Sayur-Sayuran Kota Pekanbaru. Statistik Provinsi Riau. Pekanbaru.

Rahim, dan Retno, 2008. Ekonomi pertanian. Penebar Swadaya. Jakarta. 
Dinas Tanaman Pangan Dan Hortikultura Provinsi Riau. 2011. Pekanbaru.

Dinas Tanaman Pangan dan Holtikultura Provinsi Riau. 2011. Laporan Tahunan Dinas Tanaman Pangan dan Holtikultura Provinsi Riau, Pekanbaru.

Heriyanto, H. and Darus, D., 2017. Analisis Efisiensi Faktor Produksi Karet di Kabupaten Kampar Provinsi Riau. Dinamika Pertanian, 33(2), pp.1-10

Kanwil Departemen Pertanian Provinsi Riau, 2012

Soekartawi, 2003. Analisis Usahatani, Universitas Indonesia.

Soekartawi .2002. Teori Ekonomi Produksi, Dengan Pokok Bahasan Analisis FungsiCobbDouglas, PT. Raja Grafindo Persada, Jakarta .

Soekartawi, 1987. Prinsip Dasar Ekonomi Pertanian Teori dan Aplikasinya. Rajawali Pres. Jakarta. 